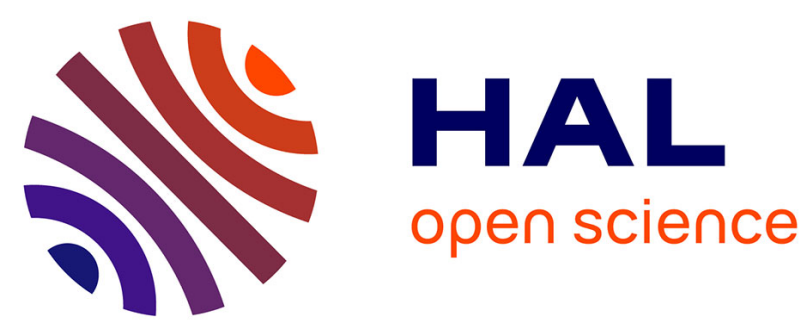

\title{
First Lebanese dragonflies (Insecta: Odonata, Aeshnoptera, Cavilabiata) from the Arabo-African mid-Cretaceous paleocontinent
}

Dany Azar, Sibelle Maksoud, Diying Huang, André Nel

\section{- To cite this version:}

Dany Azar, Sibelle Maksoud, Diying Huang, André Nel. First Lebanese dragonflies (Insecta: Odonata, Aeshnoptera, Cavilabiata) from the Arabo-African mid-Cretaceous paleocontinent. Cretaceous Research, 2019, 93 (Janvier 2019), pp.78-89. 10.1016/j.cretres.2018.08.025 . hal-01974283

\section{HAL Id: hal-01974283 \\ https://hal.sorbonne-universite.fr/hal-01974283}

Submitted on 8 Jan 2019

HAL is a multi-disciplinary open access archive for the deposit and dissemination of scientific research documents, whether they are published or not. The documents may come from teaching and research institutions in France or abroad, or from public or private research centers.
L'archive ouverte pluridisciplinaire HAL, est destinée au dépôt et à la diffusion de documents scientifiques de niveau recherche, publiés ou non, émanant des établissements d'enseignement et de recherche français ou étrangers, des laboratoires publics ou privés. 
First Lebanese dragonflies from the ‘African’ Upper Cretaceous Paleocontinent (Insecta: Odonata, Aeshnoptera, Cavilabiata)

Dany Azar ${ }^{\mathrm{a}, \mathrm{b}, *}$, Sibelle Maksoud ${ }^{\mathrm{a}, \mathrm{b}}$, Huang Diying ${ }^{\mathrm{a}}$, André $\mathrm{Nel}^{\mathrm{c}, *}$

a State Key Laboratory of Palaeobiology and Stratigraphy, Nanjing Institute of Geology and Palaeontology, Chinese Academy of Sciences, Nanjing, Jiangsu 210008, China.

${ }^{\mathrm{b}}$ Lebanese University, Faculty of Sciences II, Department of Natural Sciences, P.O. Box: 26110217, Fanar - Matn, Lebanon.

'Institut de Systématique, Évolution, Biodiversité, ISYEB - UMR 7205 - CNRS, MNHN, UPMC, EPHE, Muséum national d’Histoire naturelle, Sorbonne Universités, 57 rue Cuvier, CP 50, Entomologie F-75005, Paris, France.

*Corresponding authors: danyazar@ul.edu.lb; anel@mnhn.fr 


\section{ABSTRACT}

A new hawker dragonfly Libanoliupanshania mimi gen. et sp. nov. is described and illustrated from the lower upper Cenomanian of Hjoula (Lebanon). Its discovery shows that the Cretaceous family Liupanshaniidae, currently recorded from South America and Eurasia, was also present in the Arabo-African Cretaceous paleocontinent. Also a new 'libelluloid' family Libanocorduliidae fam. nov. is described and illustrated on the basis of the new genus and species Libanocordulia debiei gen. et sp. nov. This taxon is characterized by a unique shape of the hindwing subdiscoidal space. Paleobiogeographic implications are discussed. The 'mid' Cretaceous marine outcrop of Hjoula is potentially a new insect konservat-Lagerstätte liable to provide crucial information on the entomofauna of the paleo-Arabo-African continent at that time.

Keywords. Insecta; Odonata; Anisoptera; Liupanshaniidae, Libanocorduliidae; fam., gen. et sp. nov.; Cenomanian; Lebanon; Limestone. 


\section{Introduction}

The fossil record of the Odonata fauna of the Cretaceous Arabo-African paleocontinent is relatively scarce. To date only four taxa are known: Libanolestes flecki Azar, Prokop et Nel, 2010, a lestomorphan zygopteran of undetermined family from the Lower Barremian Lebanese amber; Jordanhemiphlebia electronica Kaddumi, 2009 (in Lak et al., 2009) a hemiphlebiid zygopteran from the Lower Cretaceous Jordanian amber; Aegyptidium aburasiensis Schlüter et Hartung, 1982, an aeschnidiid anisopteran and Gondvanogomphus bartheli Schlüter et Hartung, 1982, a gondvanogomphid stenophlebiopteran Bechly, 1996 from the putative Lower Cretaceous of South-West- Egypt (Schlüter and Hartung, 1982; Bechly, 1996; Lak et al., 2009; Azar et al., 2010). Krassilov et al. (2007) and Krassilov and Shuklina (2008) have described some egg scar insertions on leaves from the Albian of Israel. Thus the discovery of any new fossil is of great interest as this paleocontinent was isolated during the main part of the Cretaceous (Cao et al., 2017).

The dragonfly clade Aeshnoptera was very diverse during the Mesozoic, with taxa showing strong differences from their extant representatives. Among these curious forms, the Cretaceous family Liupanshaniidae Bechly et al., 2001, characterized by a very particular shape of the hindwing discoidal triangle, was widely distributed in Eurasia and South America, but hiterto unknown on the other paleocontinents (North America, Africa, Antarctica and Australia). Their apparent absence in Africa was especially surprising because the separation between South America and Africa is supposed to date back only to the very early Cretaceous (Granot and Dyment, 2015). The present discovery of a very well-preserved dragonfly belonging to this family in the Lebanese fossil fish outcrop of Hjoula (lower upper Cenomanian) shows that the Liupanshaniidae were present in the Arabo-African Cretaceous paleocontinent. 
Also the discovery of new Cavilabiata (former 'Libelluloidea') belonging to a new family (Libanocorduliidae fam. nov.) in the same outcrop is of great interest because the Cavilabiata clade is known to have greatly diversified during the Late Jurassic and the early Late Cretaceous. This family shows highly specialized wing venation structures.

\section{Outcrop, material and methods}

\subsection{Outcrop}

The studied material originated from Hjoula (Fig. 1), Caza (Department) of Byblos, Mouhafazet (Governorate) ‘Mont Lebanon’, Central Lebanon, at nearly forty kilometers North-East of Beirut. The Hjoula outcrop has historically been given several ages depending on different authors. Botta (1833) attributed the sediments in the Haqel area to the Cretaceous. Lewis (1878) and Fraas (1878) postulated a Turonian age. Later Patterson (1967) and Hückel (1970) recognized a Cenomanian age. Patterson (1967) estimated a mid-Cenomanian age on the basis of the fish fauna, whereas Hückel (1970) placed the beds at Haqel as lower Cenomanian based on the record of the foraminiferan Orbitolina concava (Lamarck, 1816) and the index ammonite Mantelliceras mantelli (Sowerby, 1814) already reported by Zumoffen (1926). Biostratigraphical studies of Dubertret $(1959,1966)$ and Saint-Marc (1974) determined the sequences at Hjoula to be lower Cenomanian. Hemleben (1977), dated them as late Cenomanian due to the assemblages of the planktonic foraminifera Praeglobotruncana stephani (Gandolfi, 1942), Rotalipora cushmani (Morrow, 1934) and Rotalipora greenhornensis (Morrow, 1934). Walley (1997) assigned the outcrop to the Sannine Formation. Recently, Wippich and Lehmann (2004) confirmed a Late Cenomanian age for Hjoula based on the presence of the ammonite Allocrioceras cf. annulatum (Shumard, 1860), which is a member of the lower upper Cenomanian Sciponoceras gracile Zone in the Western Interior of the USA and the 
Metoicoceras geslinianum Zone of the international standard. Fuchs et al. (2009), confirmed a late Cenomanian age for Hjoula as well.

During the mid Cenomanian, Lebanon was mostly submerged and positioned on a shallow carbonate platform (where there were some small islands exposed) on the North-East of the Arabo-African paleocontinent at nearly $8^{\circ}$ paleolatitude (Philip et al., 1993, Barrier and Vrielynck, 2008).

Although the deposits in the outcrop of Hjoula are clearly marine, terrestrial fossils indicate deposition close to a paleoshoreline during the early late Cenomanian, viz. terrestrial plants (pteridophytes, gymnosperms and angiosperms), invertebrates, vertebrates (complete skeletons and isolated bone of pterosaurs, turtles and fish fossils), in addition to six newly discovered complete and non-dislocate fossil dragonflies (belonging to three or four different taxa) and a fossil scarabaeoid beetle (see environmental reconstruction in Fig. 2). According to Krassilov and Bacchia (2000), this mid Cenomanian floral assemblage differs markedly from both the Lower Cretaceous and the Turonian plant assemblages of the Middle East, and represents a distinct stage of the regional floristic evolution. These authors concluded that the phytogeographic affinities of the fossil fish outcrops of the mid Cenomanian of Lebanon are with contemporaneous floras of North America, Central Europe, and the Crimea; in consequence, a combination of features like xeromorphism, the prevalence of compound leaves, and the presence of deciduous angiosperms and gymnosperms may indicate climatic conditions similar in the present day Mediterranean (Krassilov and Bacchia, 2000).

\subsection{Materials and methods}

The fossils were collected by the quarry workers. They were examined, measured and photographed using a Nicon SMZ 10 stereomicroscope with incident light equipped by camera lucida and an AmScope MU900 9MP digital camera. Habitus photographs were taken using a 
Canon EOS 60 D Camera under normal and ultraviolet lights. The raw digital images obtained on the stereomicroscope were processed with Helicon Focus stacking software, and then images were merged with Adobe Photoshop CS5.

The studied material is deposited in the Mim Museum of Mineralogy, Beirut, Lebanon.

The nomenclature of the odonatan wing venation used in this paper is based on the interpretations of Riek and Kukalova-Peck (1984), as modified by Nel et al. (1993) and Bechly (1996). The higher classification of fossil and extant Aeshnoptera follows Bechly et al. (2001). Wing abbreviations are as follows: CuA, cubitus anterior; IR1, intercalary radial veins; MA, median anterior; MP, median posterior; N, nodus; PsA, pseudo-anal vein; Pt, pterostigma; RA, radius anterior; RP, radius posterior; Sn, subnodal crossvein. All measurements are given in $\mathrm{mm}$.

\section{Systematic paleontology}

Order: Odonata Fabricius, 1793

Suborder: Anisoptera Selys in Selys and Hagen, 1954

Clade: Aeshnoptera Bechly, 1996

Family: Liupanshaniidae Bechly et al., 2001

Type genus. Liupanshania Hong, 1982 (China, Aptian to mid-Albian, 125.45 to 112.6 Ma, after Fossilworks, Paleobiology Database)

Other genera. Protoliupanshania Huang and Nel, 2010 (China, Aptian, 125 Ma), Guyuanaeschnidia Lin, 1982 (China, Aptian to mid-Albian), Araripeliupanshania Bechly et al. 2001 (Brazil, Aptian to mid Albian, 122 to 112 Ma), Paramesuropetala Bechly et al., 2001 (Brazil, Aptian to mid-Albian), Libanoliupanshania gen. nov. (Lebanon, Cenomanian), Galloliupanshania Nel et al., 2015 (France, Cenomanian), and Paraliupanshania Bechly et al., 2001 (Southern Kazakhstan, Turonian; England, Barremian). 
Genus Libanoliupanshania gen. nov.

LSID urn:

Type species: Libanoliupanshania mimi sp. nov.

Diagnosis. Wing characters only. Rspl and Mspl present but zigzagged; only two rows of cells between Rspl and IR2; a strong secondary longitudinal vein branching posteriorly from IR2; submedian space of forewing with several crossveins, while that of hindwing is free; a strong trigonal planate in hindwing; pterostigmata covering only four cells; anterior side of hindwing discoidal triangle ending at triangle apical angle; Mab strongly angled and curved; presence of a supplementary posterior branch of AA between anal triangle and anal loop in hindwing; anal loop posteriorly closed.

Etymology. Named after combination of Libano = Lebanon in Latin and Liupanshania .

Libanoliupanshania mimi sp. nov.

(Figs. 3-5)

Etymology. Named after MIM Museum where the material is deposited.

Holotype. F63, deposited in MIM Museum (a nearly complete fossil, with only legs, apical part of a forewing, and apical part of abdomen missing).

Age and outcrop. Early Upper Cenomanian, Hjoula, Lebanon.

Diagnosis. As for the genus (vide supra).

Description. Head poorly preserved, probably visible from below, $4.0 \mathrm{~mm}$ long, $6.0 \mathrm{~mm}$ wide. Thorax large, but apparently narrower than head (possible deformation due to compression), ca. $11 \mathrm{~mm}$ long, $5.6 \mathrm{~mm}$ wide.

Wings hyaline (Figs. 3-4); pterostigmata sclerotized, brown. Forewing. Length 32.2 mm; width at nodus $8.8 \mathrm{~mm}$; distance from base to arculus $4.0 \mathrm{~mm}$; distance from base to nodus $16.4 \mathrm{~mm}$; 
from nodus to pterostigma $8.8 \mathrm{~mm}$; pterostigma rather short (length $3.6 \mathrm{~mm}$; width $1.0 \mathrm{~mm}$ ), covering four cells, and braced by a weakly oblique crossvein that is aligned with its basal side; pterostigma not in a basal position; 19 postnodal crossveins, not aligned with corresponding postsubnodal crossveins; 26 secondary antenodal crossveins between costal margin and ScP, well aligned with antenodal crossveins of second row; primary antenodal crossvein Ax1 stronger than secondary antenodals, but Ax2 not well distinct from these; Ax1 just basal of arculus; six secondary antenodals between Ax1 and Ax2; basal brace Ax0 visible; 18 antesubnodal crossveins between arculus and subnodus without any gap immediately basal of subnodus; RP and MA distinctly separated at angled arculus; three bridge-crossveins Bqs basal of subnodus; base of RP2 aligned with subnodus; nodus of normal anisopteran-type; oblique vein 'O' one cell distal of subnodus; IR2 originating $2.8 \mathrm{~mm}$ and RP3/4 (midfork) $3.2 \mathrm{~mm}$ basal of subnodus; a concave, but zigzagged Rspl, not curved, with two rows of cells between it and IR2; a strong and convex secondary longitudinal vein looking like a posterior branch of IR2 three cells basal of base of Rspl; RP2 and IR2 parallel with only a single row of cells in-between, except two rows of cells near posterior wing margin; RP2 distinctly undulated on a level with pterostigma; pseudo-IR1 very weak; RP1 and RP2 closely parallel up to pterostigma (even converging near pterostigma) with only a single row of cells in-between, but below pterostigma they become strongly divergent with two or more rows of cells in-between; RP3/4 and MA parallel and weakly undulated with a single row of cells in-between (two rows near the posterior wing margin); a concave, but strongly zigzagged Mspl with one row of cells between it and MA; postdiscoidal area distinctly widened distally (width near discoidal triangle $2.6 \mathrm{~mm}$; width at posterior wing margin $5.8 \mathrm{~mm}$ ) with three rows of cells immediately distal of discoidal triangle; hypertriangle free of crossveins (length $4.8 \mathrm{~mm}$; max. width $0.5 \mathrm{~mm}$ ); discoidal triangle nearly equilateral, large, and divided into four cells; length of anterior side $2.6 \mathrm{~mm}$; of basal side $2.4 \mathrm{~mm}$; of distal side MAb $3.0 \mathrm{~mm}$; MAb straight, without a distinct convex 
secondary vein (trigonal planate) originating on it; median space free of crossveins; submedian space traversed by several crossveins plus CuP-crossing; AA divided into a strong and oblique secondary anterior branch PsA and a posterior main branch AAa, delimiting a well-defined three-celled subdiscoidal triangle, max. $2.6 \mathrm{~mm}$ long and basally $1.4 \mathrm{~mm}$ wide (= length of PsA); PsA slightly curved and ends at basal angle of discoidal triangle; a single row of cells in area between MP and CuA; MP reaching posterior wing margin on a level with nodus; $\mathrm{CuA}$ reaching posterior wing margin somewhat basal of level of nodus; six weak posterior branches of $\mathrm{CuA}$; maximum width of cubito-anal area $1.8 \mathrm{~mm}$ with maximum five rows of cells between $\mathrm{CuA}$ and posterior wing margin; anal area ma x. $2.0 \mathrm{~mm}$ wide (below PsA) with two rows of large cells between AA and posterior wing margin.

Hindwing. Length $33.6 \mathrm{~mm}$; width at nodus $10.6 \mathrm{~mm}$; distance from base to arculus $3.6 \mathrm{~mm}$; distance from base to nodus $14.0 \mathrm{~mm}$; from nodus to pterostigma $11.2 \mathrm{~mm}$; pterostigma elongated, covering four small cells (length $5.0 \mathrm{~mm}$; max. width $1.0 \mathrm{~mm}$ ); pterostigmal brace not oblique, aligned with basal side of pterostigma; 18 postnodal crossveins between nodus and pterostigma, not aligned with the 16 corresponding postsubnodal crossveins; 16 secondary antenodal crossveins between costal margin and ScP, not aligned with the second row of secondary antenodal crossveins between ScP and RA; primary antenodal crossveins aligned and distinctly stronger with about four or five secondary antenodal crossveins in-between; Ax1 slightly basal to arculus, and Ax2 two cells basal to distal angle of discoidal triangle; basal brace Ax0 visible; numerous antesubnodal crossveins in area between arculus and subnodus without any gap near subnodus; arculus weakly angled; bases of RP and MA shortly separated at arculus; three bridge-crossveins Bqs basal of subnodus; base of RP2 aligned with subnodus; only a single oblique vein 'O', one cell distal of subnodus; Rspl well-defined and straight with two rows of cells between it and IR2; a strong and convex secondary longitudinal vein looking like a posterior branch of IR2 three cells basal of base of Rspl; RP2 and IR2 more or less parallel 
with only a single row of cells in-between up to the level of pterostigma, but more distally three rows of small cells between these veins; IR2 and RP2 both strongly curved on a level with pterostigma, and RP2 even slightly undulated in this area; RP1 and RP2 are basally closely parallel (even converging near pterostigma) with only a single row of cells in-between up to pterostigmal brace vein, but more distally they become strongly divergent with two or more rows of cells in-between; pseudo-IRI weak; RP3/4 and MA parallel and only weakly undulated with a single row of cells in-between, except between their strongly curved distal parts (two rows of cells); Mspl less well-defined than Rspl, zigzagged but with a general direction straight and parallel to MAa with one row of cells between it and MA; MA and MP strongly divergent; postdiscoidal area therefore distally widened, two rows of cells in basal part of postdiscoidal area, but with about 24 small cells along posterior wing margin; four convex secondary longitudinal veins (intercalaries) in distal part of postdiscoidal area; very strong convex secondary longitudinal vein (trigonal planate), originating at strongly pronounced angle of distal side MAb of discoidal triangle and distally becoming more indistinct and zigzagged, finally ending on MP; one row of cells between trigonal planate and MA, and one row of cells between it and MP; hypertriangle free of crossveins; discoidal triangle very long, narrow, and divided into four cells by parallel crossveins; length of anterior side $3.6 \mathrm{~mm}$; of basal side 0.8 $\mathrm{mm}$; of distal side, $3.2 \mathrm{~mm}$; anterior side of discoidal triangle apically curved and ending at distal angle of discoidal triangle; MAb with a very peculiar structure, viz its basal part very concave, its distal angle very pronounced, and part distal of angle straight; median space free of crossveins; submedian space only traversed by CuP-crossing; PsA reduced to an oblique weak cubito-anal crossvein ending on basal side of discoidal triangle; subdiscoidal triangle indistinct, very small and unicellular. MP and CuA running parallel with a single row of cells in-between, except near posterior wing margin (two rows of cells); MP and CuA reaching posterior wing margin on a level with nodus; subdiscoidal veinlet reduced, and gaff very short; 
$\mathrm{CuAa}$ with five well-defined posterior branches; $\mathrm{CuAb}$ well-defined and basally curved towards wing base; cubito-anal area max. $4.6 \mathrm{~mm}$ wide with up to six rows of cells between CuAa and posterior wing margin; anal area broad (max. width $5.4 \mathrm{~mm}$ ) with up to six rows of cells between AA and posterior wing margin; anal loop posteriorly closed, well-defined; AA with two posterior branches; anal margin angular with a rather weak anal angle but a clear anal triangle, thus, it is a male specimen.

Abdomen. Preserved part 31.0 mm long; eight segments preserved; male secondary genital appendages visible on second segment; a strong constriction on segment 3.

Discussion. This fossil has all the synapomorphies of the aeshnopteran family Liupanshaniidae (Bechly et al., 2001), viz. unique shape of the very elongate and narrow hindwing discoidal triangle (anterior side of discoidal triangle distally curved and ending on the anterior side MA of hypertriangle; Mab strongly sigmoidally curved, with a very concave basal part and a strong angle in the distal part); hindwing discoidal triangle divided into several (at least three) cells by parallel crossveins; forewing discoidal triangle divided into three cells; both pairs of wings (but especially hindwing) with a strong convex secondary longitudinal vein (trigonal planate) in postdiscoidal area, originating at angle of MAb; distal accessory oblique vein between RP2 and IR2 secondarily absent.

The character 'presence of a strong, well-defined secondary vein looking like a posterior branch of IR2 basal of Rspl' is quite rare among liupanshaniids, only present in Araripeliupanshania, and absent in Guyuanaeschnidia, Liupanshania, Paramesuropetala, Paraliupanshania, Galloliupanshania, and Protoliupanshania (Lin, 1982; Hong, 1982; Bechly et al., 2001; Lin et al., 2002; Huang and Nel, 2010; Nel et al., 2015). Other differences from these genera are as follows: Paramesuropetala has a posteriorly opened anal loop and no supplementary crossvein in submedian area (Bechly, 2007); Guyuanaeschnidia has a weaker Rspl; Protoliupanshania and Galloliupanshania have a less distinctly curved and angled 
hindwing MAb; Paraliupanshania has a clearly more distinct Rspl with many more rows of cells between it and IR2, many more postnodal crossveins, a posteriorly opened anal loop, and a longer pterostigma; Liupanshania has a weaker Rspl, two rows of cells between trigonal planate and MAa close to discoidal triangle, and a longer pterostigma.

Differences between Libanoliupanshania gen. nov. and Araripeliupanshania annesusae Bechly et al., 2001 are as follows: anterior margin of hindwing discoidal triangle ending at distal angle of triangle and not on MA; presence of a supplementary posterior branch of AA between anal triangle and anal loop in hindwing; forewing postdiscoidal areas much broader; presence of four crossveins (incl. CuP) in forewing submedian area. This last character is the main difference with this genus.Unfortunately, the submedian area is only known in Araripeliupanshania and Paramesuropetala. Generally in extant Aeshnoptera, if there are numerous crossveins in the forewing submedian space, the situation is the same in the hindwing. Thus the special situation in Libanoliupanshania is also quite rare.

This new Lebanese fossil can be considered as a new genus and species, probably sister group of Araripeliupanshania for the shared special vein that 'forks’ from IR2.

The present discovery confirms that the Liupanshaniidae were present on the 'Eurasian' (including Europe), ‘South American’, and also ‘African’ Cretaceous paleocontinents. This family remains unknown in Antarctic, Australian, and North American paleocontinents. Together with the Rudiaeschnidae Bechly et al., 2001, Gomphaeschnidae Tillyard and Fraser, 1940, Burmaeshnidae Huang et al., 2017 and Enigmaeshnidae Nel et al., 2008 (Bechly et al., 2001; Nel et al., 2008; Huang et al., 2017a,b), it is one of the aeshnopteran families that diversified between the Earliest Cretaceous and the Turonian. Among them, only the Gomphaeschnidae continued into the Cenozoic, while the oldest fossil record of the extant Aeshnidae is Cenozoic. These Odonata were probably affected by the mid-Cretaceous lacustrine revolution between the Albian and the Turonian (Buatois, 2016). It appears that the 
changes in the odonatan faunas were very progressive as many 'ancient' clades survived until the Turonian (Nel et al., 2015).

Clade: Cavilabiata Bechly, 1996

Family: Libanocorduliidae fam. nov.

Type genus: Libanocordulia gen. nov.

Diagnosis. All discoidal cells transverse; hindwing subdiscoidal space broad, two-celled; vein PsA very long and strong; no Rspl; no Mspl; anal loop posteriorly closed but small, only twocelled.

Genus Libanocordulia gen. nov.

Type species: Libanocordulia debiei sp. nov.

Etymology. Named after a combination of Libano = Lebanon in Latin and Cordulia.

Diagnosis. Hindwing MP strongly zigzagged, appearing as a secondary vein between MAa and CuAa.

Libanocordulia debiei sp. nov.

(Figs 6-9)

Holotype. F64 (A and B) (part and counterpart) (Fig. 6), paratype specimen number F65 (Fig. 7A); deposited at MIM Museum of Mineralogy, Beirut Lebanon. There is one more specimen (Fig. 7B) in a private collection in Japan.

Etymology. Named after Mr. Yves Bernard Debie.

Age and outcrop. Early Upper Cenomanian, Hjoula, Lebanon.

Diagnosis. A dark band just distal of nodus in all wings. 
Description. Bodies poorly preserved. Wings hyaline except for a dark band just distal of nodus (Figs. 8-9); pterostigmata sclerotized, brown.

Holotype. Forewing: length ca. $24.8 \mathrm{~mm}$; width at nodus $6.5 \mathrm{~mm}$; distance from base to arculus $4 \mathrm{~mm}$; distance from base to nodus $13.2 \mathrm{~mm}$; from nodus to pterostigma $7.0 \mathrm{~mm}$; pterostigma long (length $2.5 \mathrm{~mm}$; width $0.6 \mathrm{~mm}$ ), covering three cells, and braced by a rather weakly oblique brace that is aligned with its basal side; pterostigma not parallel sided (distal side more oblique than basal side), pterostigma not in basal position; ca. five visible postnodal crossveins, with corresponding postsubnodal crossveins not preserved; 4-5 secondary antenodal crossveins between costal margin and ScP present distal of Ax2, antenodal crossveins of second row apparently aligned with those of first row; primary antenodal crossvein Ax1 not visible, Ax2 opposite basal side of discoidal triangle; antesubnodal crossveins between arculus and subnodus not visible; RP and MA distinctly separated at arculus; 2-3 bridge-crossveins Bqs basal of subnodus; base of RP2 aligned with subnodus; nodus of normal anisopteran-type; an oblique vein ' $\mathrm{O}$ ' more than three cells distal of subnodus; IR2 originating $1.8 \mathrm{~mm}$ and RP3/4 (midfork) $2.5 \mathrm{~mm}$ basal of subnodus; no distinct Rspl; RP2 and IR2 parallel with only a single row of cells in-between, except two rows of cells near posterior wing margin; pseudo-IR1 very weak; RP1 and RP2 closely parallel up to pterostigma with apparently only a single row of cells inbetween; RP3/4 and MA parallel and weakly curved with a single row of cells in-between (two rows near posterior wing margin); no distinct Mspl; postdiscoidal area not greatly widened distally (width near discoidal triangle $\mathrm{mm}$ ) with two rows of cells immediately distal of discoidal triangle; hypertriangle free of crossveins (length $2.6 \mathrm{~mm}$; max. width $0.4 \mathrm{~mm}$ ); free discoidal triangle transverse, quadrangular, large; length of anterior side $1.4 \mathrm{~mm}$; of basal side $1.9 \mathrm{~mm}$; of distal side MAb ca. $2.8 \mathrm{~mm}$; MAb angular, without any trigonal planate originating on it; median space free of crossveins; submedian space traversed by CuP-crossing; AA divided into a strong and oblique secondary anterior branch PsA and a posterior main branch AAa, 
delimiting a well-defined subdiscoidal triangle, max. $1.5 \mathrm{~mm}$ long and basally $1.8 \mathrm{~mm}$ wide (= length of PsA); a single row of cells in area between MP and CuA; MP reaching posterior wing margin distal nodus level; CuA reaching posterior wing margin somewhat basal of level of nodus; only one weak posterior branch of CuA; maximum width of cubito-anal area $1.3 \mathrm{~mm}$ with two rows of cells between $\mathrm{CuA}$ and posterior wing margin; anal area ma x. $1.5 \mathrm{~mm}$ wide (below PsA) with two rows of cells between AA and posterior wing margin.

Hindwing: length ca. $22.0 \mathrm{~mm}$; width at nodus ca. $9.0 \mathrm{~mm}$; distance from base to arculus 4.4 $\mathrm{mm}$; distance from base to nodus $9.7 \mathrm{~mm}$; from nodus to pterostigma $7.1 \mathrm{~mm}$; only basal half of pterostigma preserved; ca. 5-6 postnodal crossveins between nodus and pterostigma; three secondary antenodal crossveins between costal margin and ScP distal of Ax2, aligned with second row of secondary antenodal crossveins between ScP and RA; primary antenodal crossveins aligned and distinctly stronger with one secondary antenodal crossvein in-between; Ax1 just basal to arculus, Ax2 just distal to basal angle of discoidal triangle; basal brace Ax0 visible; ca. six antesubnodal crossveins in area between arculus and subnodus with a gap near subnodus; arculus straight; bases of RP and MA separated at arculus; two bridge-crossveins Bqs basal of subnodus; base of RP2 just distal to subnodus; oblique vein ' $\mathrm{O}$ ' two cells distal of subnodus; Rspl not preserved if present; distal parts of RP2 and IR2 not preserved, but only one row of cells between them in basal half; RP3/4 and MA parallel and only weakly undulated with a single row of cells in-between; Mspl apparently absent; MA and MP strongly divergent; postdiscoidal area distally widened, two rows of cells in basal part of postdiscoidal area, but with ca. four cells along posterior wing margin; no trigonal planate; hypertriangle twice as long as discoidal triangle, free of crossveins; free discoidal triangle triangular transverse; length of anterior side $1.8 \mathrm{~mm}$; of basal side $1.8 \mathrm{~mm}$; of distal side (MAb) $2.8 \mathrm{~mm}$; median space free of crossveins; submedian space apparently crossed by CuP-crossing; PsA strongly developed; a long two-celled subdiscoidal triangle; MP and CuA running parallel with a single row of cells 
in-between, but not preserved near posterior wing margin; MP and CuA probably reaching posterior wing margin on a level with nodus; $\mathrm{MP}$ and $\mathrm{CuA}$ emerging at the same point from discoidal triangle; basal part of $\mathrm{CuA}$ mm long, $\mathrm{CuAb}$ postero-basally directed; CuAa with two well-defined posterior branches; cubito-anal area max. $3.0 \mathrm{~mm}$ wide with at least five rows of cells between CuAa and posterior wing margin; anal area broad (maximum width $3.0 \mathrm{~mm}$ ) with up to six rows of cells between AA and posterior wing margin; anal loop two-celled, posteriorly closed, well-defined; AA with three posterior branches; anal margin poorly preserved.

The two other specimens are attributable to the same species because of their similar sizes and identical structure of comparable preserved parts. The specimen stored in a Japanese private collection better shows the hindwing discoidal area and the head than in the two other specimens. The eyes are apparently well separated.

Discussion. The distal part of antesubnodal area free of crossveins ('cordulegastrid gap') and the gaff (= basal CuA before its branching) of hindwing at least slightly prolonged are synapomorphies of the Cavilabiata Bechly, 1996. The absence of the basal furcation of IR2 basal of the lestine oblique vein excludes affinities with the Cordulegastrida Bechly, 1996. The pterostigmata not parallel sided, the hindwing CuAa shortened with only two branches and the large anal loop are synapomorphies of the Cristotobiata Bechly, 2003. The terminal posterior branch of CuAa secondarily branched on CuAa, the long gaff, the pterostigmata covering only two cells, and the RP3/4 and MA strictly parallel up to hind margin of wing, are synapomorphies of the Brachystigmata Bechly, 1996. The forewing discoidal triangle distinctly transverse and the two-celled elongate hindwing subdiscoidal space exclude affinities with the Nannogomphidae Bechly, 1996 and with the Hemeroscopidae Pritykina, 1977 (Pritykina, 1977; Bechly, 1996, 2003). The arculus not distinctly angled but more or less straight, the posterior part (crossvein) of arculus distinctly shorter than anterior part, and the hindwing MP distinctly curved towards hind margin and thus somewhat shortened, ending basal of the level of the 
nodus, are synapomorphies of the Neobrachystigmata Bechly, 2003. The hindwing discoidal triangle transverse, and the hypertriangles distinctly longer than triangles support affinities with the Chlorogomphida Bechly, 1996; while the anterior margin of hypertriangle nearly straight, especially in the hindwings would exclude affinities with the Paneurypalpidomorpha Bechly, 2003. Affinities with the Juracorduliidae Bechly, 2003 are excluded because of the smaller anal loop (Bechly, 1998). Nevertheless, the forewing discoidal triangle of Libanocordulia more or less transverse instead of being elongate, plus the lestine oblique veins two cells distal of the subnodus do not correspond to the situation in the Chlorogomphida. Also the two-celled anal loop strongly differs from those of the other representatives of this group that have distinctly broader anal loops (Bechly and Ueda, 2002). Thus the exact position of Libanocordulia remains uncertain. The very strong and long PsA and large subdiscoidal cell are unique characters among the whole Cavilabiata, supporting an attribution to a new family.

\section{Conclusion}

The family Liupanshaniidae was quite widely distributed in Eurasia, South America and now Africa during the Early Cretaceous, suggesting a wider distribution on all continents, a Late Jurassic origin, and an extinction during the Late Cretaceous (Nel et al., 2015). On the contrary, the Libanocorduliidae is currently restricted to the Cretaceous Arabo-African continent as is the Gondvanogomphidae, suggesting an episode of Arabo-African diversification of the Odonata during the Early Cretaceous, after the separation of this continental mass from the rest of Gondwana. It is also supporting a 'bush' diversification of the whole clade Cavilabiata at this period (Fleck et al., 1999; Nel and Huang, 2015). The Cenozoic 'survivors' of this diversification are the extant Libellulidae and related families (Zeiri et al., 2015). It is rather unusual to find only large insects in a marine outcrop (Beaury et al., 2017; Ataabadi et al., 2018). These rather large dragonflies were collected by quarry workers who are used to search 
after large fossils (fishes, etc.). Thus it is possible that a collection bias occurred. Nevertheless, the same phenomenon occurs in the historical marine Bavarian Late Jurassic outcrops in which dragonflies are much more frequent than other insects. Thus a taphonomic bias cannot be excluded too in favor to the preservation of the strong flyers. More generally, the presence of several dragonflies in the Cenomanian marine layers of Hjoula suggests that it is potentially a konservat-Lagerstätte, important for future studies of the 'mid' Cretaceous Arabo-African entomofauna that is currently nearly unknown.

\section{Acknowledgements}

We sincerely thank Rob Coram and an anonymous referee for their very useful and instructive comments on the first version of the paper. DA wants to thank as well Mr F. Escuillié for his major contribution in acquiring and donating the studied material. Financial support was provided by the Strategic Priority Research Program (B) (XDB18000000) and the National Natural Science Foundation of China (41688103). DA wants to thank the Chinese Academy of Sciences for the financial support under the CAS President's International Fellowship Initiative (PIFI). This paper is a contribution to the research project 'Characterization and sedimentological, paleontological and geochemical studies of the Lower Cretaceous dysodiles of Lebanon' financed by the Lebanese University to DA; and to the activity of the laboratory 'Advanced Micropaleontology, Biodiversity and Evolution Researches (AMBER)' at the Lebanese University.

\section{References}


Ataabadi, M.M., Bahrami, A., Mehdi Yazdi, M., Nel, A., 2018. A locust witness of a transoceanic Oligocene migration between Arabia and Iran (Orthoptera: Acrididae). Historical Biology, https://doi.org/10.1080/08912963.2017.1378651

Azar, D., Prokop, J., Nel, A., 2010. The first damsel fly from the Early Cretaceous Lebanese amber (Odonata, Zygoptera, Lestomorpha). Alavesia 3, 73-79.

Barrier, E., Vrielynck, B., 2008. Palaeotectonic maps of the Middle East: tectono-sedimentarypalinspastic maps from Late Norian to Pliocene. Atlas of 14 maps at 1/18 500 000. Publisher CGMW, Paris, France.

Beaury, B., Krogmann, L., Nel, A., 2017. The first fossil insect from the deep-water marine Early Miocene of Zillerleite, Germany (Diptera: Bibionidae). Palaeontologia Electronica 20.3.61A, 1-5.

Bechly, G., 1996. Morphologische Untersuchungen am Flügelgeäder der rezenten Libellen und deren Stammgruppenvertreter (Insecta; Pterygota; Odonata), unter besonderer Berücksichtigung der Phylogenetischen Systematik und des Grundplanes der Odonata. Petalura Special Volume 2, 402 pp.

Bechly, G., 1998. Juracordulia schiemenzi gen. et sp. nov., eine neue Libelle aus den Solnhofener Plattenkalken (Insecta: Odonata; Anisoptera). Archaeopteryx 16, 29-36.

Bechly, G., 2003. Description of a new species of Nannogomphus (Insecta: Odonata: Nannogomphidae) from the Upper Jurassic Solnhofen Limestone in Germany. Stuttgarter Beiträge zur Naturkunde (B) 339, 1-6.

Bechly, G., 2007. Chapter 11.5 Odonata: damselflies and dragonflies. pp. 184-222. In: Martill, D., Bechly, G. and Loveridge, R. (eds). The Crato fossil beds of Brazil: Window into an ancient world. Cambridge University Press, Cambridge, 624 pp.

Bechly, G., Ueda, K., 2002. The first fossil record and first New World record for the dragonfly clade Chlorogomphida (Insecta: Odonata: Anisoptera: Araripechlorogomphidae n. fam.) from 
the Crato Limestone (Lower Cretaceous, Brazil). Stuttgarter Beiträge zur Naturkunde (B) 328, $1-11$.

Bechly, G., Nel, A., Martínez-Delclòs, X., Jarzembowski, E.A., Coram, R., Martill, D., Fleck, G., Escuillié, F., Wisshak, M.M., Maisch, M., 2001. A revision and phylogenetic study of Mesozoic Aeshnoptera, with description of several new families, genera and species (Insecta: Odonata: Anisoptera). Neue Paläontologische Abhandlungen 4, 1-219.

Botta, P.E., 1833. Observations sur le Liban et Anti-Liban. Mémoires de la Société Géologique de France 1, 135-160.

Buatois, L., Labandeira, C.C., Mángano, M.G., Cohen, A. and Voigt, S. 2016. The Mesozoic lacustrine revolution. In: Mángano, M.G. and Buatois, L.A. (eds.). The trace-fossil record of major evolutionary events. Topics in Geobiology 40, 179-263.

Cao, Wenchao, Zahirovic, S., Flament, N., Williams, S., Golonka, J., Müller, R.D., 2017. Improving global paleogeography since the late Paleozoic using paleobiology. Biogeosciences 14, 5425-5439.

Dubertret, L., 1945. Carte géologique de la Syrie et du Liban. Délégation générale de France au Levant, Section géologique.

Dubertret, L., 1959. Contribution à la stratigraphie et à la paléontologie du Crétacé et du Nummulitique de la marge N.W. de la péninsule arabique. Notes et Mémoires sur le Moyen Orient 7, 193-220.

Dubertret, L., 1966. Liban, Syrie et bordure des pays voisins. Tableau stratigraphique avec carte géologique au millionième. Notes et Mémoires sur le Moyen-Orient 8, 251-358.

Dubertret, L., Wetzel, W.C., 1945. Carte géologique de la Syrie et du Liban. Délégation générale de France au Levant, Section géologique.

Fleck, G., Nel, A., Martínez-Delclòs, X., 1999. The oldest record of the Libellulidae from the Upper Cretaceous of Kazakhstan (Odonata, Anisoptera). Cretaceous Research 20, 655-658. 
Fraas, O., 1878. Geologisches aus dem Libanon. Jahreshefte des Vereins für vaterländische Naturkunde in Württemberg 34, 257-391.

Fuchs, D., Bracchi, G., Weis, R., 2009. New octopods (Cephalopoda: Coleoidea) from the Late Cretaceous (Upper Cenomanian) of Hâkel and Hâdjoula, Lebanon. Palaeontology 1, 6581.

Gandolfi, R., 1942. Ricerche micropaleontologiche e stratigrafiche sulla Scaglia e sul Flysch cretacici. Revista Italiana di Paleontologia, Memoria 4, 1-160.

Granot, R., Dyment, J., 2015. The Cretaceous opening of the South Atlantic Ocean. Earth and Planetary Science Letters 414, 156-163.

Hemleben, C.V., 1977. Rote Tiden und die oberkretazischen Plattenkalke im Libanon. Neues Jahrbuch für Geologie und Paläontologie, Monatshefte 4, 239-255.

Hong, Y.-C. 1982. [Class Insecta.] pp. 85-100. In: [The Mesozoic stratigraphy and paleontology of the Guyang coal-bearing basin, Neimenggol Autonomous Region, China.] Geological Publishing House, Beijing. [In Chinese].

Huang, Diying, Cai, Chenyang, Nel, A., Bechly, G., 2017a. A new dragonfly family from the mid-Cretaceous Burmese amber (Odonata: Aeshnoptera: Burmaeshnidae). Cretaceous Research 78, 8-12.

Huang, Di-ying, Nel, A., 2010. Protoliupanshania wangi, a new genus and species from the Chinese Early Cretaceous (Odonata: Aeshnoptera: Liupanshaniidae). Zootaxa 2387, 57-62. Huang, Diying, Nel, A., Cai, Chenyang, 2017b. A new Burmese amber hawker dragonfly helps to redefine the position of the aeshnopteran family Burmaeshnidae (Odonata: Anisoptera: Aeshnoidea). Cretaceous Research 79, 153-158.

Hückel, U., 1970. Die Fischschiefer von Haquel und Hajoula in der Oberkreide des Libanon. Neues Jahrbuch für Geologie und Paläontologie Abhandlungen 135, 113-149.

Krassilov, V., Bacchia, F. 2000. Cenomanian florule of Nammoura, Lebanon. Cretaceous 
Research 21, 785-799.

Krassilov, V., Shuklina, S., 2008. Arthropod trace diversity on fossil leaves from the midCretaceous of Negev, Israel. Alavesia 2, 239-245.

Krassilov, V.A., Silantieva, N., Hellmund, M., Hellmund, W., 2007. Insect egg sets on angiosperm leaves from the Lower Cretaceous of Negev, Israel. Cretaceous Research 28, 803811.

Lak, M., Fleck, G., Azar, D., Engel, M.S., Kaddumi, H.F., Néraudeau, D., Tafforeau, P., Nel, A 2009. Phase contrast X-ray synchrotron microtomography and the oldest damselflies in amber (Odonata: Zygoptera: Hemiphlebiidae). Zoological Journal of the Linnean Society 156, 913-923.

Lamarck, J.B.P.A. de M., 1816. Liste des objets représentés dans les planches de cette livraison. Tableau encyclopédique et méthodique des trois règnes de la nature. Vers, coquilles, mollusques et polypiers. Paris: Agasse. 16 pp.

Lewis, E.R., 1878. The fossil fish localities of the Lebanon. Geological Magazine 2:214-220.

Lin, Qi-bin, 1982. [Insecta.] pp. 329-332. In: [Paleontological atlas of East China, Late Paleozoic.] (ed. Nanjing Institute of Geology and Mineral Resources). Geological Publishing House, Bejing, 1-495. [in Chinese]

Lin, Qi-bin, Nel, A., Huang, Di-Ying, 2002. Phylogenetic analysis of the Mesozoic dragonfly family Liupanshaniidae (Insecta: Aeshnoptera: Odonata). Cretaceous Research 23, 439-444. Morrow, A.L., 1934. Foraminifera and Ostracoda from the Upper Cretaceous of Kansas. Journal of Paleontology 2, 186-205.

Nel, A., Fleck, G., Garcia, G., Gomez, B., Ferchaud, P., Valentin, X., 2015. New dragonflies from the lower Cenomanian of France enlighten the timing of the odonatan turnover at the Early - Late Cretaceous boundary. Cretaceous Research 52, 108-117. 
Nel, A., Huang, Diying, 2015. A new family of 'libelluloid’ dragonfly from the Middle Jurassic Daohugou in northeastern of China (Odonata: Anisoptera: Cavilabiata). Alcheringa 39, 525529.

Nel, A., Martinez-Delclos, X., Paicheler, J.-C., Henrotay, M., 1993. Les 'Anisozygoptera' fossiles. Phylogénie et classification (Odonata). Martinia Numéro Hors Série 3, 1-311.

Nel, A., Néraudeau, D., Perrichot, V., Girard, V., Gomez, B., 2008. A new dragonfly family in the Upper Cretaceous of France (Insecta: Odonata: Aeshnoptera). Acta Palaeontologica Polonica 53, 165-168.

Patterson, C., 1967. New Cretaceous berycoid fishes from the Lebanon. Bulletin of British Museum of Natural History Geology 14, 69-109.

Philip, J., Babinot, J.F., Tronchetti, G., Fourcade, E., Azema, J., Guiraud, R., Bellion, Y., Ricou, L.E., Vrielynck, B., Boulin, J., Cornee, J.J., Herbin, J.P. 1993. Late Cenomanian Palaeoenvironments (94-92 Ma). In: Atlas Tethys Palaeoenvironmental Maps. Maps (J. Dercourt, L. E. Ricou, and B. Vrielynck, eds.), BEICIP-FRANLAB, Rueil-Malmaison.

Pritykina, L.N., 1977. [New dragonflies from Lower Cretaceous deposits of Transbaïkalia and Mongolia.] In: Fauna, flora i biostratigrafiya mezozoya i kaynozoya Mongolii [Fauna, Flora, and Biostratigraphy of the Mesozoic and Cenozoic of Mongolia.] Trudy Sovmestnaya Sovetsko-Mongol'skaya Paleontologicheskaya Ekspeditsiya 4, 81-96. [in Russian.]

Riek, E.F., Kukalova-Peck, J., 1984. A new interpretation of dragonfly wing venation based upon Early Carboniferous fossils from Argentina (Insecta: Odonatoidea) and basic characters states in pterygote wings. Canadian Journal of Zoology 62, 1150-1166.

Saint-Marc, P., 1974. Etude stratigraphique et micropaléontologique de l’Albien, du Cénomanien et du Turonien du Liban. Notes et Mémoires sur le Moyen Orient 13, 8-42.

Schlüter, T., Hartung, M., 1982. Aegyptidium aburasiensis gen. nov., spec. nov. (Aeschnidiidae) und Gondvanogomphus bartheli gen. nov., spec. nov. (Gomphidae) aus mutmasslicher Unterkreide Südwest-Ägyptens (Anisoptera). Odonatologica 11, 297-307. 
Shumard, B.F., 1860. Descriptions of new Cretaceous fossils from Texas. Transactions of the Academy of Sciences of St. Louis 1, 560-610.

Sowerby, J., 1812-1814. The mineral conchology of Great Britain; or coloured figures and descriptions of those remains of testaceous animals or shells, which have been preserved at various times and depths in the earth (Vol. 1). Benjamin Meredith, Silver Street, Wood Street, Cheapside. 235 pp.

Tillyard, R.J., Fraser, F.C., 1940. A reclassification of the order Odonata based on some new interpretations of the venation of the dragonfly wing. Part 3. The Australian Zoologist 9, 359396.

Walley, C.D., 1997. The lithostratigraphy of Lebanon: a review. Lebanese Science Bulletin 1, 81-107.

Wippich, M.G., Lehmann, J., 2004. Allocrioceras from the Cenomanian (mid-Cretaceous) of the Lebanon and its bearing on the palaeobiological interpretation of heteromorphic ammonites. Palaeontology 5, 1093-1107.

Zeiri, A., Nel, A., Garrouste, R., 2015. A new libelluloid family from the Eocene Green River Formation (Colorado, USA) (Odonata, Anisoptera). Zootaxa 4032, 290-296.

Zumoffen, G., 1926. Géologie du Liban. H. Barrere, Paris, 165 pp.

Figures

Fig. 1. Outcrop of Hjoula, Caza (Department of Byblos), Mouhafazet (Governorate) 'Mont Lebanon’, Central Lebanon, at nearly fourty kilometers North-East of Beirut. A. Geological map of Hjoula adapted from a partial combination of the geological maps of Jbail (Dubertret, 1945) and Quartaba (Dubertret and Wetzel, 1945) 1/50000. C2a = Jezzinian, oolitic yellow limestone; C2b = Jezzinian, white mudstone limestone; C3 = Albian; C4 = Cenomanian; Thickened lines indicate faults. B. General view. 
Fig. 2. Reconstruction of the palaeoenvironment of Hjoula during the early late Cenomanian. Copyright Huang Diying.

Fig. 3. Libanoliupanshania mimi gen. et sp. nov., holotype F63. A. Photograph of general habitus. B. Photograph under ultraviolet light. Scale bars: $10 \mathrm{~mm}$.

Fig. 4. Libanoliupanshania mimi gen. et sp. nov., holotype F63. Detail of wings. Scale bar: 10 mm.

Fig. 5. Libanoliupanshania mimi gen. et sp. nov., holotype F63. Reconstruction of fore- and hindwing. Scale bar: $10 \mathrm{~mm}$.

Fig. 6. Libanocordulia debiei gen. et sp. nov., holotype F64. Photographs of general habitus. A. Imprint. B. Counterimprint. Scale bars: $10 \mathrm{~mm}$.

Fig. 7. Libanocordulia debiei gen. et sp. nov. Photographs of general habitus. A. Paratype F65. B. Specimen in a private collection. Scale bars: $10 \mathrm{~mm}$.

Fig. 8. Libanocordulia debiei gen. et sp. nov. Forewings. A. Right, holotype F64 A. B. Left, holotype F64 A. C. Right wings of holotype F64 B. D. Right, paratype F65. Scale bars: 10 mm. Fig. 9. Libanocordulia debiei gen. et sp. nov. Hindwings. A. Right, holotype F64 A. B. Left, holotype F64 A. C. Right, paratype F65. Scale bars: 10 mm. 

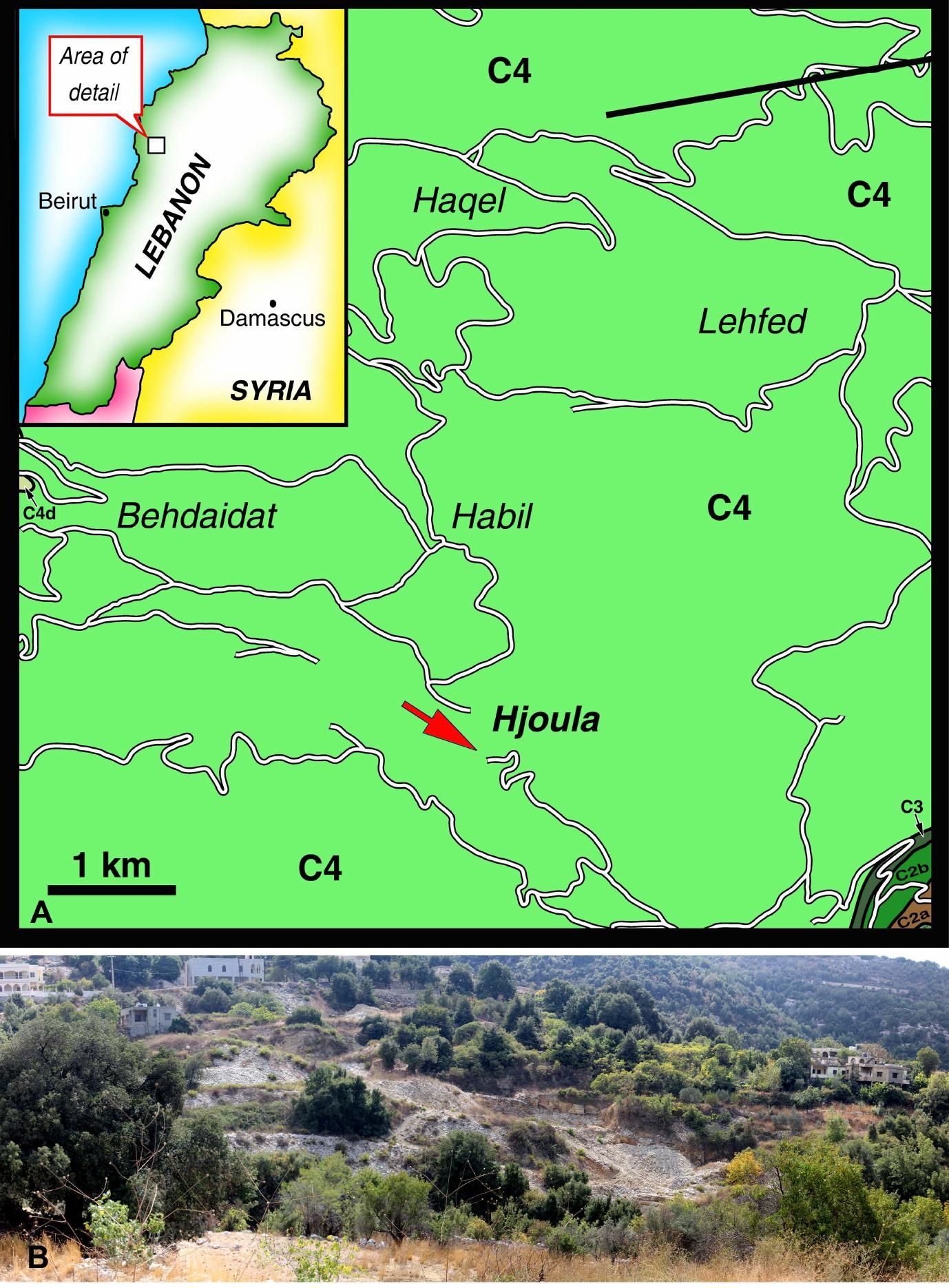


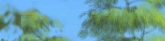

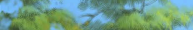

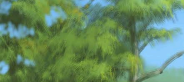

- $x^{2} x^{2}-a^{2}-t^{2}$

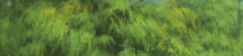

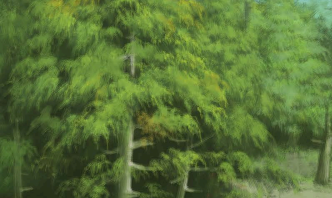

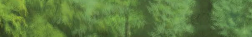

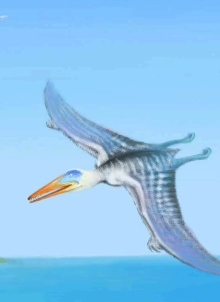

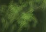

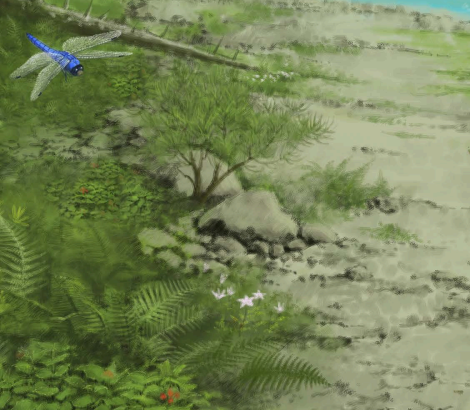

$$
\text { Deriouet }
$$
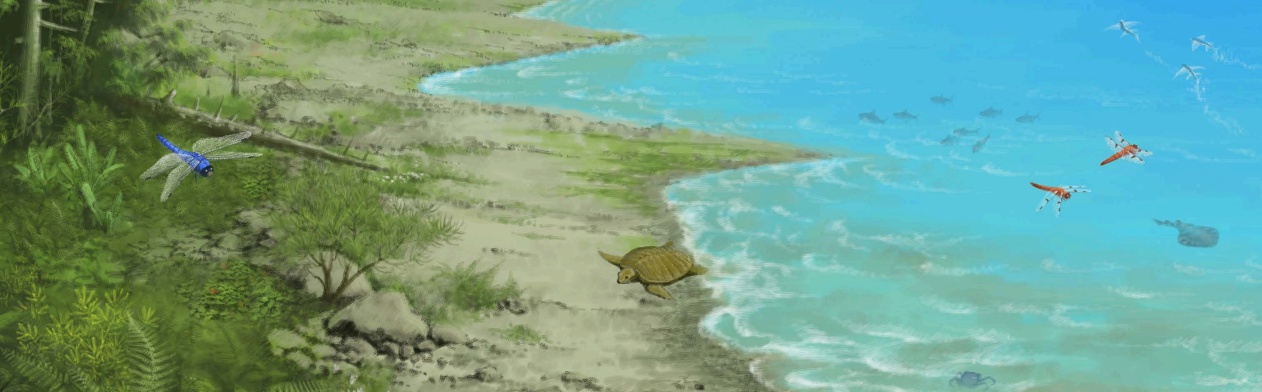



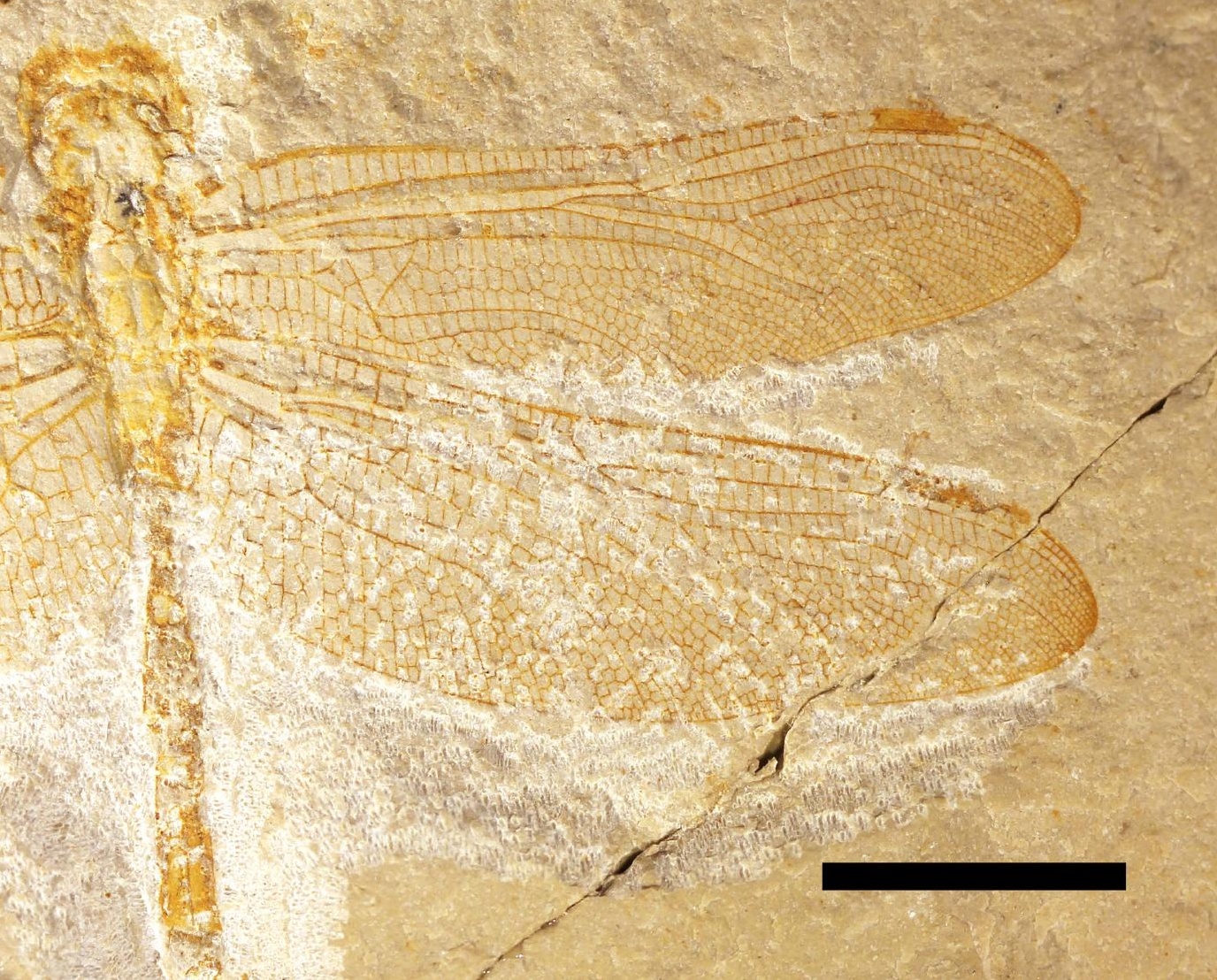




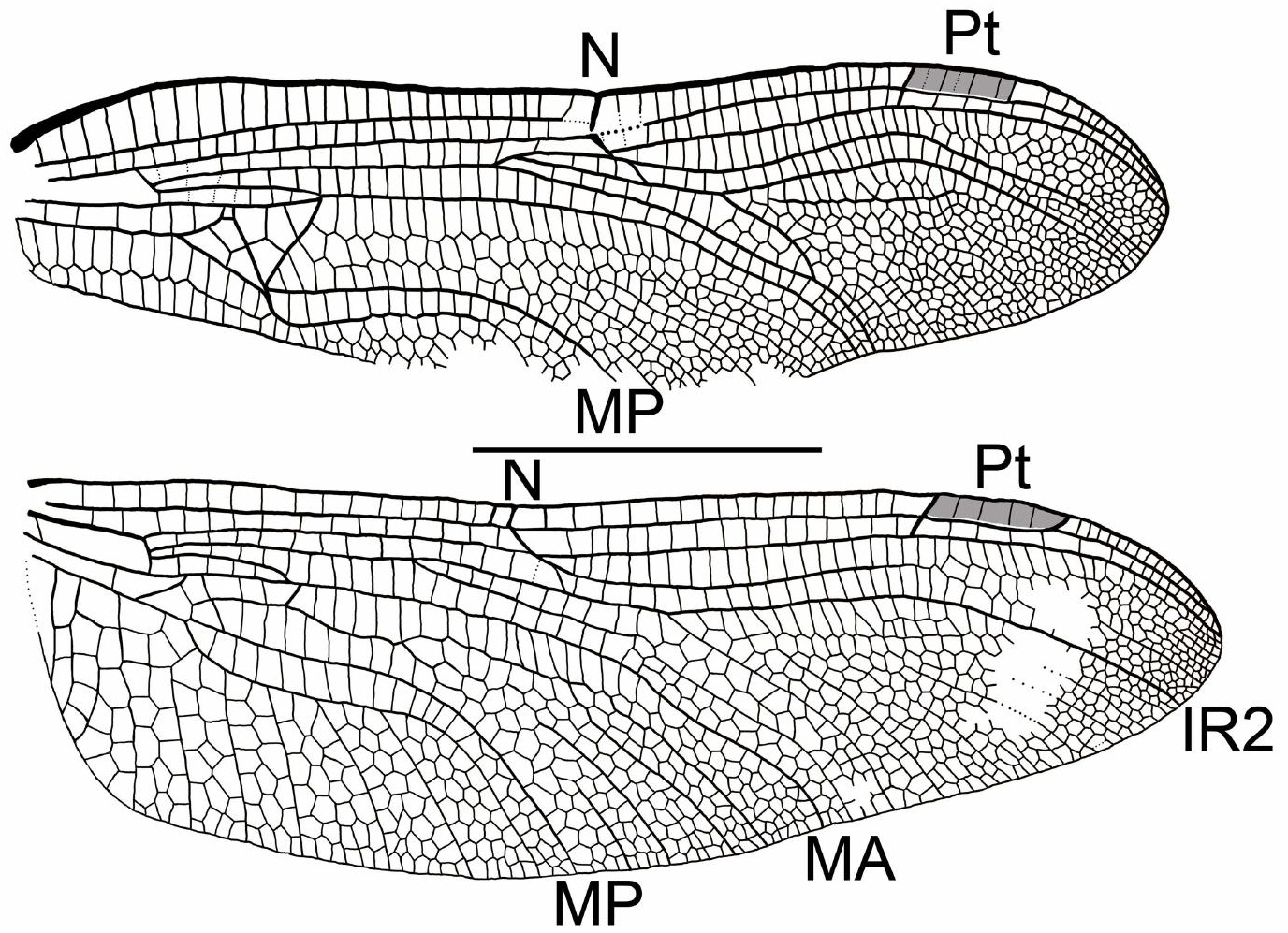




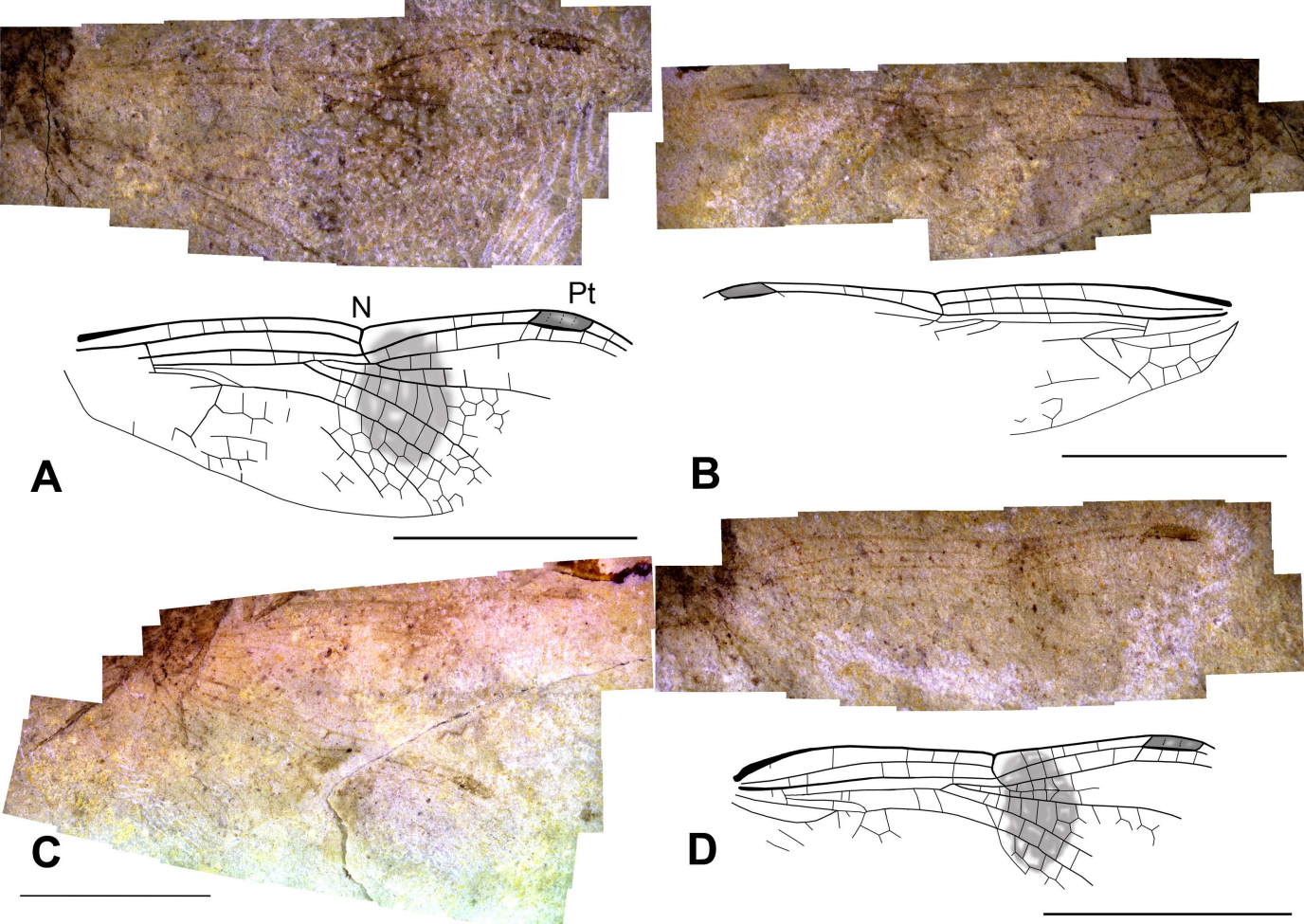


